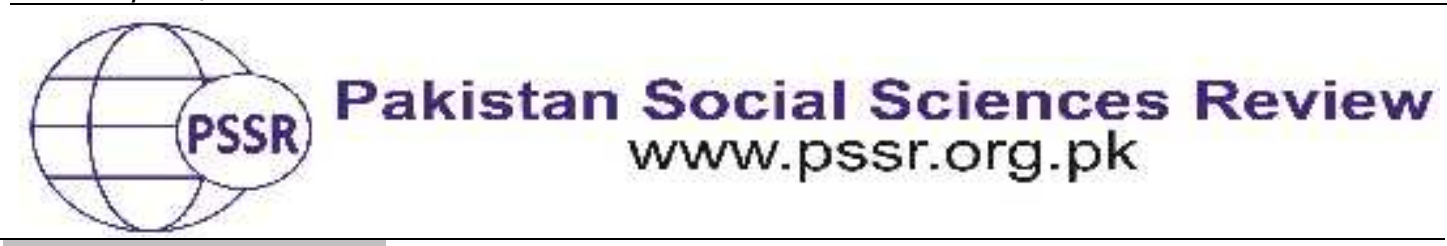

RESEARCH PAPER

\title{
Understanding Supervisor-Doctoral Student Relationship: A Qualitative Interview Study in Austrian Universities
}

\author{
Dr. Syed Abdul Waheed
}

Assistant Professor, Department of Educational Research \& Assessment, University of Okara, Okara, Punjab, Pakistan

\begin{tabular}{|c|c|}
\hline PAPER INFO & ABSTRACT \\
\hline $\begin{array}{l}\text { Received: } \\
\text { March 07, } 2021 \\
\text { Accepted: } \\
\text { May 01, } 2021 \\
\text { Online: } \\
\text { May 15, } 2021\end{array}$ & $\begin{array}{l}\text { Doctoral students' relationship with supervisors and co- } \\
\text { supervisors supports their socio-academic integration and } \\
\text { contributes to their academic success. The study purports to } \\
\text { explicate a deeper understanding of doctoral students' lived } \\
\text { experience of how they tend to develop their relationship with }\end{array}$ \\
\hline $\begin{array}{l}\text { Keywords: } \\
\text { Academic } \\
\text { Adjustment, } \\
\text { Academic } \\
\text { Relationship, } \\
\text { Doctoral Students, } \\
\text { Phenomenology, } \\
\text { Research Supervisor, } \\
\text { Supervisor } \\
\text { Relationship } \\
\end{array}$ & $\begin{array}{l}\text { the supervisors and how they assist them in adjusting to the } \\
\text { university's institutional environment. Eleven purposively } \\
\text { selected doctoral students described their experiences in } \\
\text { response to open-ended questions posed in the semi-structured } \\
\text { interviews. A phenomenological approach was employed to } \\
\text { execute the study and analyze the qualitative data (Van Manen, } \\
\text { 1997). As a result, significant thematic aspects were identified } \\
\text { from the participants' conversations that include 'supportive } \\
\text { relationship', 'friendly and informal interaction' and 'interactive }\end{array}$ \\
\hline $\begin{array}{l}\text { *Corresponding } \\
\text { Author }\end{array}$ & $\begin{array}{l}\text { communication'. The emergent themes informed that most of } \\
\text { the doctoral students experienced positive and supporting } \\
\text { relationships with the supervisors and co-supervisors that } \\
\text { helped them integrate into the university's academic } \\
\text { communities. The study has implications for the supervisors and } \\
\text { doctoral students for establishing and strengthening the } \\
\text { academic relationships. }\end{array}$ \\
\hline
\end{tabular}

\section{Introduction}

Working, living and studying in another country requires establishing a positive, healthy and supportive relationship with the host nationals. Many international students have different socio-academic cultures at home universities and need to be academically well-adjusted for their success and satisfaction. Erichsen and Bollinger (2011) described that most international students could not establish Moreover, Pyhältö, Stubb, \& Lonka (2009) found that students' attachment with their fellows and other academic communities differs while studying abroad. They added that nearly thirty per cent of doctoral students were found isolated or had an inappropriate relationship with the other people in their academic circles. 
International students are curious about the structure of the academic department, socio-academic environment of the host university's institution and culture when they first enter a foreign country. Most academic departments have different norms and values that influence students' performance, adjustment, and experiences with other students and faculty (Le \& Gardner, 2010; Lechuga, 2011). In other words, the students and faculty significantly contribute to the development and social adjustment of international students in a foreign university (Bista, 2016; Bista \& Gaulee, 2017; Cowly \& Ssekasi, 2018; Khanal \& Gaulee, 2019; Li, Wang, Liu, Xu, \& Cui, 2018; Li \& Zizzi, 2018; Gardner, 2010; Jones, 2013; Weidman, \& Stein, 2003). In particular, international students' assistance in emotional and professional matters is considered the most important and salient feature of their institutional adjustment that helps them cope with other crucial problems during their studies (Khanal \& Gaulee, 2019; Li \& Zizzi, 2018; Martinez, Ordu, Della Sala, \& McFarlane, 2013; Spaulding \& Rockinson-Szapkiw, 2012).

A supervisor is the most critical professional and scholarly person for doctoral students who becomes crucial when the students commence their research work and need frequent interactions and viable guidance from him. The studentsupervisor relationship begins when a supervisor agrees to supervise a student through a formal consent letter. Muhar, Visser, \& Breda (2013) found in their research with doctoral students in sustainability from Austria and South Africa that "not all supervisors are experienced enough, capable and willing to engage in interand transdisciplinary research. On the other hand, co-supervision from other institutions can help extend the limited capacity and provide additional inputs from different perspectives" (p. 127). Moreover, the student-supervisor relationship helps enhance the ability to reduce disruptions.

The research shows that the student-supervisor relationship depends upon match or mismatch between them, which affects students' performance (Hilmer \& Hilmer, 2007). The supervisors should be effective guide, pleasant counsellor, influential trainer and good critic for engaging students in guiding them (Bista \& Gaulee, 2017; Li \& Zizzi, 2018; Spillett, \& Moisiewicz, 2004). Also, the supervisors are academicians and researchers, and should not behave bureaucratically (Barnes \& Austin, 2009). Also, Barnes, Williams, \& Archer (2010) inferred that "the advising relationship has an important impact on student satisfaction as well as student outcomes such as degree completion or attrition" (p. 37). Besides, Knigge-Illner (2002) described that "PhD students do not get much attention at German universities. They are not integrated into a special course of studies. And in most cases, they even do not get much assistance from their supervisors" (p. 164).

The academic communities of the institution play a significant role in integrating and adjusting students in the academic department through establishing a relationship with scholarly communities of the university, particularly of the academic department (Tinto, 1993). Tinto stressed that "one must take note of the full range of individual experiences which occur in the formal and informal domains of both the social and academic systems of the institution" (p. 118). The 
interactionalist model is "a model of educational communities that highlights the critical importance of student engagement or involvement in the learning communities" of the institution (Tinto, 1993, p. 133). The present study is an attempt to explore the nature of doctoral students' experiences of relationship within the institution that led them to the academic adjustment in the department.

\section{Research Questions}

The following research main questions were designed to guide the present research study.

- How did students experience the relationship with their supervisors and cosupervisors during executing doctoral research projects?

- How did doctoral students' experiences of relationship help them in adjusting to the academic environment of the university?

\section{Material and Methods}

The present study aims at understanding doctoral students' experiences of relationship with their research supervisors and co-supervisors. The study was planned to uncover students' interaction, relationship and how communication plays an essential role in establishing a relationship with the supervisors. Based on the students' lived experiences, phenomenological research fit the purpose of the study and the research questions (Creswell, 2018). Eleven Pakistani doctoral students working on their research project were approached purposively from different public sector universities of Austria. Most of them had been awarded foreign $\mathrm{PhD}$ scholarship for four years from the Higher Education Commission of Pakistan. Also, some of the participants were having scholarship from an Austrian university, and a few were studying on their own.

Based on the research questions of the study, an interview guide consisting of semi-structured questions was developed. The interviews provide an opportunity to understand participants' life world directly from their experiences and interaction with the environment and the meanings they assign to their feelings and emotions (Kvale, 1996). According to Spradely, the purpose of employing interviews in qualitative research is reflected by the researcher's intention that, "I want to understand the world from your point of view... I want to understand the meaning of your experience, to walk in your shoes, to feel things as you feel them, to explain things as you explain them." (Spradley, cited in Kvale, p. 125). A short demographic questionnaire consisting of questions on participants' key characteristics was used to interpret their experiences and interviews were conducted after seeking permission through a consent form. All the interviews were audio-recorded with the participants' consent.

The audio-recorded interviews were transcribed by the researcher and a reflective process was employed to understand the meaning of doctoral students' 
understanding of the phenomenon of relationality. The interview recordings listened, and text was read repeatedly to have an in-depth understanding of participants' nature of experiences of relationship. Van Manen (1997) denoted that "the insight into the essence of a phenomenon involves a process of reflectively appropriating, of clarifying and of making explicit the structure of the meaning of the lived experience" (p. 77). The transcripts were coded while reading them frequently and the emerging themes were formulated through highlighting and selective approaches of analysis (Van Manen, 1997)

\section{Results and Discussion}

The study aimed to explore doctoral students' relationship with their supervisors and faculty of the universities in Austria. As a result of their interactional experiences and relationships as early career researchers, doctoral students attempted to socialize themselves within the institutional environment to become engaged therein for the utmost utilization of educational opportunities. The doctoral students' experiences of relationship with their supervisors described the nature of the relationship and how they affected their personal and academic life. As a result of the analysis of the interview transcripts, the themes; supportive relationship, friendly and informal interaction, and interactive communication emerged, which are described in the following section.

\section{Supportive Relationship}

The participants of the study considered the supervisor as one of the most influential persons in their life who can affect doctoral students' research career, and relationship with the supervisors can determine their success in future. The participants described their relationship with the supervisors in two perspectives; supervisor as a person and supervisor as a professional guide. The doctoral students studying in Austrian universities had different experiences of interaction and prelateships with their supervisors working in various fields of study.

It was observed from the participants' experiences that they had a healthy, supportive and respectful relationship with their supervisors. The supervisors were found very respectful towards their supervisees. Yasmin was surprised to see the respectful and good-will gestures from her supervisor. She stated that "My supervisor stood up with respect when I entered his office. It was unusual for me because it never happened in my life. He was my supervisors and 'boss'."

Another participant, Daud was doing his doctoral studies in a technology university. He had a fatherly relationship with his supervisor and named this relationship as "doctor father" used in the German context. He experienced that Austrian supervisors were more friendly than the Scandinavians, where he had completed his master degree. Nevertheless, he added that one of the reasons was that he was swamped in his job there and could not frequently interact with his supervisor at that time. He elaborated that 
His supervisor, who was at his middle age, was very polite, humble and respectful. He treated me like a father who loves his children. He guided me like a father who holds his child's finger and takes him to the way. He guided me in a way that I can learn on my own to become an independent researcher.

He explained that the student-supervisor relationship is based on mutual trusting and respect, and the privacy of this relationship is protected by both persons. On the other hand, one cannot establish a good relationship with the supervisor if a student is not positively responded to by the supervisor. He specified that "The response from the supervisor breaks or builds up the relationship."

Similarly, another participant named Salman, a doctoral student in biomedical sciences, remarked that his supervisor was very positive towards what he had been doing in the research project, and she always encouraged him with healthy and supportive arguments. His supervisor did not discriminate against him during the meetings and seminars, and she always valued his perspective. She did not pressurize him by giving unnecessary deadlines. Although she required that the research work should be "perfect", but it did not cause stress for his students. Salman believed that this type of positive attitude helps to establish a good working relationship and the quality of the research.

Some of the participants remarked that they were encouraged and appreciated by their supervisors "more than they deserved". Ismaeel was doing a doctorate in computer sciences, and his supervisor never challenged and pressured him that he always wished. Ismaeel said that his supervisor "never asked me to write this and don't write that. Perhaps it is everywhere that professors have limited influence in projects or PhDs". He desired that his supervisor should "force" him to do a research task, to achieve a goal, or win a massive project, but he had been busy in his projects, perhaps to earn money and never paid attention to what he wanted to do. Most of the times, he encouraged by saying that "you did a great job", but Ismail was not satisfied with these remarks. He stated:

"I wanted to do something big... For example, I was thinking perhaps I would become a great researcher and will produce something very innovative not existing in the market... Nevertheless, my supervisor was not concerned with my inner concerns... And if you are always told that you did a great job, then your motivation dies... I want someone to say to me, 'you didn't do well."

Some of the doctoral students have a diverse working relationship with supervisors from a different academic background, such as Finland, Germany, and Austria. One of such doctoral students who had worked with different supervisors remarked that "Your supervisor is your point of focus whether you are in a European university or in an American university... Your supervisor's behaviour and attitude matter for your performance". He was of the view that the supervisor is a human being, and this aspect of the personality matters in establishing a supportive relationship. His supervisor was very supportive in academic and personal matters. 
He described that "My supervisor is down to earth. She never made me realize that she is my boss or my supervisor. She was more worried about my funding than I was when I came here... Sometimes she goes out of her way to take actions in my favour."

\section{Friendly and Informal Interaction}

Doctoral students believed in a friendly relationship with their supervisors. A doctoral student Yousuf studying in a veterinary university, experienced that a friendly supervisor can guide his students well. He reflected that "If your supervisor is frank and friendly, you learn in a better way than if he is strict because if you work under pressure, you don't do things as you wish to do". It was also revealed from the participants' experiences that they wished to interact directly with their supervisors rather than that contacting the post-doctoral research fellows was more comfortable than the supervisors. Yousuf added that "sometimes it is difficult to interact with your supervisor directly because one may feel more comfortable with a post-doctoral colleague and can share the ideas with him without any hesitation." It is better to talk to the senior colleague because most of the supervisors are very busy in their research projects. They are not readily available for quick advice that novice researchers need.

Another doctoral student Danyal was doing a dissertation in a field of physical sciences. He remarked that "It is always beneficial and everlasting if a doctoral student has a friendly and cordial relationship with a supervisor, and one should not go against him." He further added that a "doctoral student should not step beyond the expectations of a supervisor."

Some of the doctoral students were happy to find a very "flexible and open" supervisor in addressing students' needs and has given much liberty to them. Yasmin was a doctoral student in computer sciences, and she changed her supervisor and joined him again. She was happy to find that her supervisor did not bother after joining him again. She remarked, "I took advantage of the flexibility of my professor's personality. Due to this, I was able to continue my Masters as well." Sometimes, she did not agree with her supervisor's point of view. The supervisor respected her point of view and did not react aggressively.

Some doctoral students were aware that their supervisors were not expert and technically skilled in an area of research; therefore, the students hesitated to ask a question so that supervisor's self-respect could not be hurt. Such student could not frequently interact with the supervisors that deteriorated establishing a relationship with them and they sought alternative ways of guidance for the research.

Having two supervisors, particularly when an "official supervisor" has debuted another professor to supervise his student, may affect doctoral student's relationship with either of the supervisors or with both of them. Yaqoob was a doctoral student in a technological university, and he faced such a situation in the 
university. Both the supervisors had some difference of opinion that bothered the student. The deputed supervisor focused more on his students and did not give priority to Yaqoob being a student of another supervisor. Also, some of the resources like equipment were available with the official supervisor that the deputed supervisor could not approach to and request for the student's use. This particular situation affected doctoral student's performance and relationship.

There were doctoral students, who had an only formal relationship with the supervisors. The students desired to have an informal and friendly interaction with the supervisor to have a socially interactive environment in the department that can satisfy them in their personal life. Maryam had such a supervisor about which he reflected:

"My supervisor is very straightforward... and very strict... maybe due to his age... Technically, he is sound, responsive and good at giving comments. Nevertheless, he is only a supervisor who has no social life and does not have a heart... Even he never asks me how I am!... You know he is not supervising a robot; he is supervising a social human being, and a human being is linked with many other things."

It was observed while transcribing the interviews and analyzing the text that doctoral students' compare each other's supervisors when they assess them in their private life, and as a result, they develop certain feelings toward their supervisor and others'. Maryam had many complaints about her supervisor. She described that "sometimes, I feel awful if I hear something socially good about a supervisor of my colleague, my heart starts weeping... Nevertheless, now I am used to expecting and accepting this type of behavior." However, she further explained that "it seems that indirectly he understands my situation... You know he never gives me pressure and deadlines because he has an understanding that I have a family life." It was interesting to know what she expects from her supervisor as an ideal person. On this question, she reflected that "it would cast a very positive effect if my supervisor had a pleasant behaviour toward me one day; I would feel myself to be very happy and lucky... I would work more productively; his words would play magic."

The doctoral students experienced that their relations with their students significantly contributed to their success and satisfaction in life. They were of the view that the supervisor was more important than their choice of visiting Austria. Most of the participants were happy to find a helping, supportive, respectful and friendly supervisor. Nevertheless, few 'strict', 'unsocial', 'formal' and 'incompetent' supervisors affected students' performance, personal life, professional development, and relationship.

\section{Interactive Communication}

The doctoral students had a professional and supportive relationship with other faculty of the university department, particularly those who were their co- 
supervisors and helping them in the research matters. The co-supervisors worked with the doctoral students while coordinating with their first supervisors. The participants described that 'work' pays in the long run and students' effort and their interest in the dissertation determines the nature of their relationship with the supervisors and co-supervisors. Ibrahim was a doctoral student in biological sciences who remarked that "your supervisor can understand you by your work and behaviour." He added:

"Everybody has some properties and traits that one's supervisor is observing. So, perhaps our understanding was developed after she [supervisor] observed such things... For example, I don't try to hide the results [of my experiments], and I give her the exact picture of the results... I don't ask somebody to do my experiments... Thus, she believes that I am doing things correctly whatever I do."

Communication is significantly essential in guidance and receiving feedback from the supervisors. The doctoral students may hesitate to interact with them while they feel comfortable conversing with their senior colleagues in the department. Ibrahim, a veterinary medicine student, reflected that "The communication that I made with my post-doc colleagues was quite different to that which I had with my supervisor... Later, I started to communicate with my supervisor directly, and there was no problem." He further explained that communicating directly with the supervisors has another meaning. He further remarked that it means, "How you would plan and execute your research. Also, how you would work out and how you would present your research results and outcomes. There was a little bit of confrontation or difference of opinion in the beginning."

Similarly, some participants communicated with their supervisors either on skype or through emails, particularly when they were away from their workplace. Salman experienced that he had effective and result-oriented communication with his supervisor. In urgent matters, he can call her supervisor on the telephone. He elaborated, "I can go to her room without making an appointment, I can talk to her any time regarding my matters and my education... especially about my $\mathrm{PhD}$. She is available for us every time".

Doctoral students' past experiences with their master supervisors had pleasant effects while pursuing their doctoral studies. Maryam, a student of business and economics at the University of Economics, had a healthy relationship and 'good communication' with her previous supervisors in England. She stated, "Actually, I had a very different view about the supervisor that I had when I was a Masters student in [another European country]. My supervisor was outstanding and very sociable. When your supervisor is sociable, you feel good in communicating."

It was revealed from participants' experiences that some doctoral students had excellent communication with their supervisors that helped them establish a friendly relationship. Ismaeel's supervisor was an expert and specialized person in his research field and was a good communicator. He responded to him quickly, 
sometimes within hours, even if he was not present in the university. He was very interactive. Ismaeel described that "I have very close and friendly relations with him... He often takes me for a meal... He always has a smiling face; he is a very gentle and nice man... He treats everybody equally and perhaps treats the foreigners in a better way... He is not a horrible boss; he is a true manager and professional... Nevertheless, he has less knowledge of my topic because it is not his field."

He explained that her supervisor was an expert in communication. She consistently communicated in such a way that does not hurt him and does not realize him that he was wrong even sometimes he was not on the right move. She did not remark that he committed a mistake rather she commented, "I would have done this work in this way if I would have been working in your place." Salman reflected, "I feel motivated and encouraged this way. I am satisfied concerning research, international exposure, and with respect to learning."

Nevertheless, some of the supervisors are not so expressive, communicate well and make a promise. One has to run after them to remind that one has a commitment and needs to have your time. Yaqoob remarked that "such supervisors are very busy, affecting their communication and attitudes with their students." His supervisor shared that "I am giving money to whom I am giving time'... If he says that 'I will meet you tomorrow at three', he will not; you will have to run after him again the next day."

The theme suggests that communication matters a lot in determining the supervisory relationship. It was revealed while exploring this theme that the supervisors were friendly, open and flexible who had free and enough time for their students to communicate with them effectively.

The supervisor as a person and a professional researcher was deemed significantly necessary by the doctoral students whose attitudes, behaviors', and communication methods affected their work experience and the relationship. The study participants have described their experience regarding the two aspects of the supervisors and have given meanings to their experiences. Maryam, who found her supervisor "unsocial" described that, "Technically, he is sound... On the social side, he is only a supervisor who has no social life and does not have a heart... He never even asks me how I am, really!... You know he is not supervising a robot; he is supervising a social human being..."

Participant was asked, what do you mean by being a "social person"? How would you like your supervisor to be, and what would happen if your supervisor becomes very social one day? She imagined and described that that "it would cast a very positive light... I will be delighted... I will feel myself to be very lucky... I would work more productively that day... his words will play magic". In relevance to this finding, it was argued by Rockinson-Szapkiw's (2012) that the social-personal fit between the scientific communities in the universities is as significant as the academic match between the supervisor and doctoral students. On the other hand, 
the mismatch between the supervisors and doctoral students can cause dissatisfaction, maladjustment, and unhealthy relationship that further give rise to leaving the program (Cowly \& Ssekasi, 2018; Khanal \& Gaulee, 2019; Li \& Zizzi, 2018; Golde, 2005; Jairam \& Kahl Jr., 2012).

It was found that some of the supervisors were extraordinarily helpful, friendly and flexible in their attitudes towards students. The result of this study shows that the supervisors demonstrated respect to their students. Yasmin was such a student who commented that "he warmly welcomes me, he even stands up and opens the door for me which most of the time seems to be a bit strange because he is my supervisor". Similarly, Daud was happy to have a supervisor who had "fatherly" relationship with his supervisor and considered him a "doctor father". He observed that "student-teacher relationship was very "friendly" in Austria. The supervisor guides him like a father guides his child with love, respect, and humbleness," and this relationship is developed through trust."

In this connection, Muhar, Visser, and Breda (2013) described, "the German term DoktorVater ("Doctoral Father") characterizes the sometimes rather paternalistic connotation of this relationship quite clearly" (p. 123). Also, Wei, Tsai, Chai, Du, and Lin (2012) investigated "the moderators of general or cross-cultural advisory working alliances and perceived English proficiency in the association between acculturative stress and psychological distress" of East Asian international students. The students perceived the resemblance of the role that parents and supervisors play at home and in the universities, respectively. Nevertheless, it was suggested that "the formerly bilateral relationship between supervisor and doctoral candidate (individual supervision) should be broadened to integrate the candidate into a team, for example as part of a doctoral program" (Universities Austria, 2007, p. 36).

It was noticed that the study participants had diverse experience with the supervisors and faculty of the department where they worked on the projects. Morris (2011) identified various aspects of a student-supervisor relationship that revealed its nature as dynamic and evolving. He gave different forms of the relationship such as "exploitative", "aggressive", and "intrusive" which may cause many problems in the life of students. Nevertheless, most of the doctoral students were happy to see their supervisors as friendly, supportive, and informal in dealing with them in their personal and professional life". Merleau-Ponty (1962) argued that individuals connect to other people through dialogue, and they are affirmed through the process of dialogue. Also, how we think, communicate and act are shared and subject to change during life (Burch, 1991). Also, Burch (1991) stated that "the lived experience in and through which we come to also constitute our basic ontological understanding of other beings encountered within the world" (p. 59). 


\section{Conclusion}

The doctoral students experienced their relationship as supportive, friendly and informal with interactive communications with the supervisors. It seems that the students perceived their relationship on a continuum of relationality that ranged from a supervisor who was extremely "unsocial" to one who was like a father. This range of experiences describes the nature of the relationship with the supervisors. The doctoral students described their relationship because of their experiences and feelings such as 'lucky', 'unlucky', 'happy', 'respectful', 'trusted', 'productive', treated with 'love', 'respect' and 'humbleness', 'supportive', 'welcoming', 'frank', 'friendly', 'flexible', 'encouraging', 'busy', 'strict', 'discriminating' and 'inexpert'. Some doctoral students have to fulfill the university's requirements, the home and the workplace, which limited their chances to interact with supervisors and other faculty. The study has implications for establishing a healthy and supportive relationship with the supervisors. 


\section{Reference}

Barnes, B. J., \& Austin, A. E. (2009). The role of doctoral advisors: A look at advising from the advisor's perspective. Innovative Higher Education, 33(5), 297-315.

Barnes, B. J., Williams, E. A., \& Archer, S. A. (2010). Characteristics That Matter Most: Doctoral Students' Perceptions of Positive and Negative Advisor Attributes. NACADA Journal, 30(1), 34-46.

Bista, K. (2016). Examining the research on international students: Where are we today? Journal of International Students, 6(2), I-X.

Bista, K., \& Gaulee, U. (2017). Recurring themes across fractal issues facing international students: A thematic analysis of 2016 dissertations and theses. Journal of International Students, 7(4), 1135-1151. doi: 10.5281/zenodo.103598

Burch, R. (1990). Phenomenology, lived experience: Taking a measure of the topic. Phenomenology + Pedagogy, 8, 130-160.

Cowley, S. P., \& Ssekasi, D. H. (2018). Motivation, induction, and challenge: Examining the initial phase of international students' education. Journal of International Students, 8(1), 109-130. doi: 10.5281/zenodo.1101039

Creswell, J. W. (2018). Research Design: Qualitative, Quantitative, and Mixed Methods Approaches. Fifth edition. Los Angeles: SAGE.

Erichsen, E. A. \& Bollinger, D. U. (2011). Towards understanding international graduate student isolation in traditional and online environments. Educational Technology Research and Development. 59. 309-326.

Gardner, J. W. (1952). The foreign student in America. Foreign Affairs, 30, 637-650.

Gardner, S. K. (2007). "I heard it through the grapevine": Doctoral student socialization in chemistry and history. Higher Education, 54,123-140.

Gardner, S. K. (2010). Faculty perspectives on doctoral student socialization in five disciplines. International Journal of Doctoral Studies, 5, 39-53.

Golde, C. M. (2005). The role of the department and discipline in doctoral student attrition: Lessons from four departments. The Journal of Higher Education, 76(6), 669-700.

Hilmer, C. E., \&Hilmer, M. J. (2007). On the relationship between student-advisor match and early career research productivity for agricultural and resource economics PhDs. American Journal Agricultural Economics, 89(1), 162-75. 
Jairam, D., \& Kahl Jr., D. H. (2012). Navigating the doctoral experience: The role of social support in successful degree completion. International Journal of Doctoral Studies, 7, 311-329.

John, T., \&Denicolo, P. (2013). Doctoral Education: A Review of the Literature Monitoring the Doctoral Student Experience in Selected OECD Countries(Mainly UK). Springer Science Reviews, 1, 41-49.

Khanal, J., \&Gaulee, U. (2019). Challenges of international students from pre departure to post-study: A literature review. Journal of International Students, 9(2), 560-581.

Knigge-Illner, H. (2002). Doing one's PhD - A dramatic interplay of cognition, motivation and emotion. In G. Rott, G. F. Dias, \& Jean-Paul Broonen (Eds.), Cognition, motivation and emotion: Dynamics in the academic environment (pp. 166176). Fedora Psyche Conference in Lisbon, FEDORA: Louvain-la-Neuve.

Kvale, S. (1996). Interviews: An introduction to qualitative research interviewing. London: Sage Publications.

Lechuga, V. M. (2011). Faculty-graduate student mentoring relationships: mentors' perceived roles and responsibilities. Higher Education. 62. 757-771.

Li., J., Wang, Y., Liu, X., Xu, Y., \& Cui, T. (2018). Academic adaptation among international students from East Asian countries: A Consensual qualitative research. Journal of International Students, 8(1), 194-214. doi: 10.5281/zenodo.1134289

Li, S., \& Zizzi, S. (2018). A case study of international students' social adjustment, friendship development, and physical activity. Journal of International Students, 8(1), 389-408. doi: 10.5281/zenodo. 113431

Martinez, E., Ordu, C., Della Sala, M. R., \& McFarlane. A. (2013). Striving to obtain a school-work-life balance: The full-time doctoral student. International Journal of Doctoral Studies, 8, 39-59.

Morris, S. E. (2011). Doctoral Students' Experiences of Supervisory Bullying. Pertanika Journal of Social Sciences and Humanities, 19(2), 547-555.

Muhar, A., Visser, J. \& Breda, J. V. (2013). Experiences from establishing structured inter- and transdisciplinary doctoral programs in sustainability: A comparison of two cases in South Africa and Austria. Journal of Cleaner Production, 61,122-129.

Pyhältö, K., Stubb, J., \&Lonka, K. (2009). Developing scholarly communities as learning environments for doctoral students. International Journal for Academic Development, 14(3), 221-232. 
Pyhältö, K., Toom, A., Stubb, J., \&Lonka, K. (2012). Challenges of becoming a scholar: A study ofdoctoral students' problems and well-being. International Scholarly Research Network, 1-12.

Seidman, I. (2013). Interviewing as qualitative research: A guide for researchers in education and the social sciences. New York: Teachers College Press.

Spaulding, L. S. \&Rockinson-Szapkiw, A. J. (2012). Hearing their voices: Factors doctoral candidates attribute to their persistence. International Journal of Doctoral Studies, 7, 199-219.

Spillett, M. A., \&Moisiewicz, K. A. (2004). Cheerleader, coach, counselor, critic: Support and challenge roles of the dissertation advisor. College Student Journal, 38(2), 246-55.

Tinto, V. (1993). Leaving college: Rethinking the causes and cures of student attrition (2nd ed.). Chicago: The University of Chicago Press.

Tinto, V. (2012). Completing college: Rethinking institutional action.Chicago, IL: University of Chicago.

Van Manen, M. (1997). Researching lived experience: Human science for an action sensitive pedagogy. London, Ontario: The Althouse Press.

Van Manen, M. (2014). Phenomenology of practice: Meaning-giving methods in phenomenological research and writing. CA: Left Coast Press, Inc.

Wei, M., Tsai, P.-C., Chai, R. C.-L., Du, Y., \& Lin, S.-P., (2012). Advisory working alliance, perceived English proficiency, and acculturative stress. Journal ofCounseling Psychology. 59(3). 437-448.

Weidman, J. C., \& Stein, E. L. (2003). Socialization of doctoral students to academic norms. Research in Higher Education, 44, 641-656. 